University of Nebraska - Lincoln

DigitalCommons@University of Nebraska - Lincoln

Center for Great Plains Studies: Staff and

Fellows Publications

Great Plains Studies, Center for

2009

\title{
The Impact of Military Forts on Agricultural Investments on the Great Plains in 1880
}

Christopher S. Decker

University of Nebraska at Omaha, christopherdecker@unomaha.edu

David T. Flynn

University of North Dakota, david.flynn@UND.edu

Follow this and additional works at: https://digitalcommons.unl.edu/greatplainsfellows

Part of the Other International and Area Studies Commons

Decker, Christopher S. and Flynn, David T., "The Impact of Military Forts on Agricultural Investments on the Great Plains in 1880" (2009). Center for Great Plains Studies: Staff and Fellows Publications. 1.

https://digitalcommons.unl.edu/greatplainsfellows/1

This Article is brought to you for free and open access by the Great Plains Studies, Center for at DigitalCommons@University of Nebraska - Lincoln. It has been accepted for inclusion in Center for Great Plains Studies: Staff and Fellows Publications by an authorized administrator of DigitalCommons@University of Nebraska Lincoln. 


\title{
The Impact of Military Forts on Agricultural Investments on the Great Plains in 1880
}

\author{
by \\ Christopher S. Decker \\ and \\ David T. Flynn \\ Department of \\ Economics \\ College of Business Administration \\ College of Business \& \\ Public \\ University of Nebraska at Omaha \\ Omaha, NE 68164 \\ Dakota \\ and \\ Administration \\ University of North \\ 58202 \\ Research Fellow \\ Center for Great Plains Studies \\ University of Nebraska at Lincoln \\ Lincoln, NE 68588
}

\begin{abstract}
We empirically investigate the relationship between agricultural development and proximity to military forts in Kansas, Nebraska, and Colorado in 1880. Agricultural investments are substantially higher in counties where a military fort is present, suggesting that military forts stimulated agricultural development on the Great Plains. However, the reverse is not true; there is no statistical support for the notion that forts necessarily located in counties where substantial development was already occurring. Moreover, we found that while the presence of a military fort has the effect of increasing agricultural development, there is no evidence that such a presence sustained agricultural development.
\end{abstract}

Keywords: Forts, Great Plains, Agriculture

JEL Codes: N51, N91, R11, R53 


\begin{abstract}
We empirically investigate the relationship between agricultural development and proximity to military forts in Kansas, Nebraska, and Colorado in 1880. Agricultural investments are substantially higher in counties where a military fort is present, suggesting that military forts stimulated agricultural development on the Great Plains. However, the reverse is not true; there is no statistical support for the notion that forts necessarily located in counties where substantial development was already occurring. Moreover, we found that while the presence of a military fort has the effect of increasing agricultural development, there is no evidence that such a presence sustained agricultural development.
\end{abstract}

Keywords: Forts, Great Plains, Agriculture

JEL Codes: N51, N91, R11, R53

\title{
I. Introduction
}

The role of government in fostering economic growth is a contentious issue in contemporary economic development as well as the historical development of the United States and its various regions. For instance, consensus generally supports the notion that state and local taxation acts as a drag on economic growth (Becsi, 1996). However, investment in public infrastructure 
financed through taxes and bond issuance tends to generally support private sector growth (Chandra and Thompson, 2000).

From a historical perspective, there are additional examples of private sector benefits of governmental investments. Craft (1998) finds that government installation of weather reporting stations on coastal areas around the Great Lakes in the late nineteenth century reduced shipping accidents, though the success of other nineteenth century policies is questionable. Lindert (1993) discussed government subsidization as one of the major influences on farmland prices. Notable among these are the various public land disposal policies of the era.

The Homestead Act of 1862 was designed to promote settlement and agricultural investments on the American Frontier. Evidence recently published by Stewart (2006) shows substantial wealth accumulation in Kansas, Nebraska, and the Dakotas in the 1860s and 1870s attributable to the Homestead Act. However, general consensus is the policy, as well as other subsequent land disposal acts, was largely a failure, particularly in the western and northern Great Plains. This failure was due largely to the fact that the provisions in the policy (offering 160 acres to settlers free with the promise of a five year tenure and land improvement efforts) attracted an unsustainably large number of small, assetlimited, farmers to the region (Hanson and Libecap, 2003). While there was evidence some farm operations were successful for a time, during periods of severe drought, crop yields fell and incomes plummeted. Moreover, the farms 
themselves were too small to exploit scale economies and other advantages from large scale operations that would help them sustain operations in such an arid region (Libecap and Hansen, 2002). Olson and Naugle (1997, p. 160) document that in Nebraska, of the 131,561 persons who filed homestead entries in 1862, only 68,862 received final patents in 1900 . Fully 48 percent of all homestead operations in Nebraska failed by 1900 and many of these were in the western part of the state, west of the $98^{\text {th }}$ meridian where annual precipitation falls off dramatically (Webb, 1931).

While the evidence is fairly clear, particularly in the arid western regions of the Great Plains, governmental efforts to transfer public land to smaller, private concerns failed to foster sustained economic enterprise, there are some examples that would appear to run counter to this trend. According to the Tenth Decennial Census of the United States 1880: Volume III: Report on the Production of Agriculture, average land values for Nebraska and Kansas counties east of the $98^{\text {th }}$ meridian was about $\$ 12.00$ per acre. Moreover the average share of improved acreage to total was 56.5 percent. However, in Arapahoe County in Colorado, land sold for over $\$ 15$ per acre with roughly 32 percent of the county's acreage experiencing capital improvements. Moreover, in Lincoln County, Nebraska, another county west of the $98^{\text {th }}$ meridian, 78 percent of the land was subject to improvements and land there was valued at $\$ 8.56$ per acre. Finally, in Costilla County, Colorado, 72 percent of the land was subject to improvements, indicating 
a substantial amount of agricultural investment. While land there was valued at $\$ 4.74$ per acre, this rate was substantially larger than the average land value in six eastern Kansas and Nebraska counties, such as Cheyenne County, Kansas where land was valued at $\$ 2.17$ per acre.

There are several possible reasons for why these arid counties appeared to have experienced some relative success. Both Arapaho County, Colorado and Lincoln County, Nebraska benefited from railroad access as well as river access for cultivation and irrigation. However, neither a substantial river nor railroad was present in Costilla County, Colorado in 1880. There were no major population centers to support demand for agricultural goods either. It is perhaps quite telling, however, that Fort Garland operated in this county between 1853 and 1883.

In this paper, we address the role the frontier army played in the development of the American West, specifically as it relates to agricultural investment, the primary motivation behind the Homestead Act of 1862 and many subsequent US land policies. There are at least three reasons why proximity to military forts on the frontier would offer and incentive for farmers to invest in land improvement activities. ${ }^{1}$ Soldiers and fort personnel in general represented a

\footnotetext{
${ }^{1}$ As Dobak (1998, p. 7) points out, most histories of the frontier army's role in the American West "ignores relations between military posts and the surrounding communities: whether the army and the market it afforded helped attract settlers; or who got the army's money, how they spent it, and how that affected the community." As we hope to document in this paper, both the historical
} 
source of demand for local agricultural output. The historical record is replete with stories of local communities benefitting from military expenditures on locally available provisions and food stuffs as well as indirect benefits of skilled brought to satisfy fort demands (Freedom, 1976, 97). In his extensive history of Fort Riley, Kansas, Dobak (1998, p. 5) documents how farmers located near the fort were elated by the arrival of substantial cavalry companies in 1880 as it meant increased demand for hay and feed grain for companies' horses. West (1998, p. 276) writes that "troops were consumers - in their case especially voracious ones - of the vituals around them." (p. 276). He further added that local "enterprises quickly struck up a dynamic give-and-take with the posts. Freedom (1976, p. 82) suggests significant buying from local area producers occurred after the local population and transportation network developed sufficiently. Road stores catered to the soldiers' daily needs and vices and also supplied emigrants and travelers moving west. The soldiers and fort represented the retail market for local stores. Early ranchers found a market for their cattle, farmers for their grains, pumpkins, cabbages, onions, and other produce.” (p. 276). Such relationships were quite lucrative prospects for local farmers indeed. In his extensive study of the role the frontier army played in the development of the American West, Tate (1999, p. 119) indicates one of the most lucrative military contracts was for the supply and delivery of beef, mutton, and other food

record and the supporting statistical analysis show that the activities of the frontier army did have a substantial role to play in the frontier economy of the nineteenth century. 
stuffs to military posts. According to Tate these contracts were second in value only to larger construction project contracts. ${ }^{2}$ To the extent, then, that the presence of a nearby military fort stimulated demand for agricultural goods, farmers located in these areas had incentives to increase production to meet this demand and possibly secure military contracts, creating an incentive for increased land improvement activities. Until local activity reached sufficient scale fort needs were met by producers from outside the immediate region (Freedom, 1976, p. 85).

Many soldiers also engaged in limited agricultural activities on military posts. Tate (2007, p. 51-54) describes instances of military personnel extensively experimenting with novel agricultural techniques including dry land farming. Freedom (1987) documented many army writings about trial-and-error planting and harvesting techniques ultimately published, booster newspapers and other periodicals that were distributed in the Eastern United States and Europe to attract settlement. Robinson (1977) points out that gardening was indeed encouraged at forts and that soldiers engaged in such activities disseminated their experiences through libraries and reading rooms. Forts also enhanced access to

\footnotetext{
${ }^{2}$ The impact of a military presence on a local economy is certainly not limited to the nineteenth century American West. Other historical examples include Dunn, Jr. (2002) documenting the critical role the British Army played in private enterprise development after the end of the French and Indian war in 1763. Moreover, it has been demonstrated that rural contemporary economies in the United States are adversely affected by the closing of a nearby military bases, although there is debate as to the long term magnitude of such impacts on local communities (see, e.g. Hooker and Knetter, 2001).
} 
communication sources such as mail and the telegraph. Freedom (1976) identified agicultural knowledge as the significant contribution of military agriculture in the settlement of the northern Plains. Dobak (1998, p. 61, 63) also offers examples of military personnel remaining in settlements near the forts where they were stationed after their terms of enlistment ended to take up many vocations, including private farming activities. One might expect increased investment activities in areas near forts where successful and novel cultivation activities were proven beneficial and where additional private farming activities took place by retiring army personnel.

Finally, a military presence likely encouraged investment by deterring farm property pilfering and destruction by Indian raiders attempting to prevent white settler encroachment on their land or outlaw bandits. As Hart (1963, p. 118) describes, "Regardless of where they were, or why, the citizens of nineteenth century America felt the deserved protection from the Army.” Freedom (1987) documents several instances where several forts were established in the Dakota Territories largely to protect white settlements. ${ }^{3}$

The economic history of the American west is largely a story of public land disposal, westward migration, and, importantly, the establishment and

\footnotetext{
${ }^{3}$ For example, according to Freedom (1987), Fort Dakota, near present day Sioux Falls, South Dakota and Fort Ellis near Bozeman, Montana were established largely to protect settlement in those regions. While these areas are outside our study area due to the fact that neither the Dakotas nor Montana were states and thus we have no county level data for the period of focus here, these examples highlight the importance of frontier forts as protectors.
} 
enforcement of private property rights, a stark contrast with the economic history of the American east (Anderson and Hill, 1975, 1990; Anderson and Leal, 1991). A focus on property right protection is therefore germane. Secure property rights increase individual incentives to invest in innovation and production because of the reduced dissipation of economic rents through theft, arbitrary confiscation, contractual holdup, or other rent-seeking activities (North;1987, 1990). Many studies support the idea that secure and enforceable property rights, whether governmental or privately developed institutions, promote economic growth (Thorstensson, 1994; Domcer, 2007) and investment, both internationally (Besley, 1995), and within the context of the nineteenth century American west (Anderson and Hill, 2004, p. 22; Kanazawa, 2006).

The role of the frontier army as protectors of private property, however, is not immediately obvious. It does appear to be the case that a number of military forts, such as Fort Kearny in Nebraska, were established to protect emigrants moving west along the Platte River road from Indian raids, outlaws, etc. (Frazier, 1988, p. 87). That said, the task of establishing federal policing powers without encroaching on citizens' civil liberties has pre-occupied legislators and policy makers since the inception of the United States. The Judiciary Act of 1789 was the first attempt to delineate the relationship between local marshals and federal enforcement of law. With respect to the nineteenth century American west, the 1878 amendment to that year's military appropriations act advanced by 
Representative William Kimmel of Maryland severely restricted military involvement in civil enforcement and established penalties for military personnel who stepped beyond the delineations established by the act. ${ }^{4}$ These restrictions were not without controversy. In 1871 Secretary of War William Belknap cited many examples of how soldiers had coordinated with local law enforcement to make arrests, detain prisoners, prevent thievery, etc. (Tate, 1999, p. 3). Indeed, speaking of military officers' attitudes towards their delineated federal powers to intervene in civil affairs, Tate (1999) describes:

At times, the majority preferred a loose interpretation of that power, thus allowing them to arrest and hold small numbers of outlaws and rioters for short periods of time. They well recognized that the more remote areas of the West lacked sufficient civilian law enforcement personnel to deal with some of these problems. Even under the threat of possible legal reprisal for arresting civilians, most military officers carried out their duties with dedication." (p. 110).

In short, one would expect a military presence could reasonably be seen as a source of civil protection, at least for transportation routes, thereby reducing the threat of rent dissipation and fostering investment activities.

While the three reasons detailed support the notion that establishment of military installations in the American west tends to support economic growth and investment, it could be that such establishments hindered local and regional growth and investment, particularly in agriculture. Dobak (1998, p. 1977)

\footnotetext{
${ }^{4}$ In effect, the act restricted military action to exceptional cases of insurrection or riot, the endangerment of public (not private) property, and efforts to disrupt federal mail service.
} 
articulates this view well by pointing out that the military did sequester acres of land for military purposes, closing many areas to settlement and homesteading and limiting the tax base for local government. These activities likely had a detrimental impact on private sector activities.

The opposing views make the question of the frontier army's role in the development of the west is an empirical one. The paper is organized as follows. In sections II and III we describe the scope of the study, empirical model variables and data sources. In section IV we address specifics element of the estimation procedure. In section $\mathrm{V}$ we present the model results and in section VI we conclude and offer avenues for future research.

\section{Nature and Scope of Empirical Analysis}

The empirical analysis conducted here uses county data mostly from tables published in the Tenth Decennial Census of the United States of 1880 (Census), compiled by the Inter-University Consortium for Political and Social Research (ICPSR), and focuses on the region defined by the states of Kansas, Nebraska and Eastern Colorado (about 179 total counties). Our dependent variable is the proportion of improved county acreage, defined as ACIMP, obtained from the

Census. Since the historical census of the United States for 1880 does not appear to have tracked a direct measure of agricultural investment, ACIMP serves as a proxy for investment in that it measures acreage subject to improvement for cultivation purposes, such as the clearing of brush and trees, leveling/landscaping 
of land for growing crops, land tillage, irrigation networks, etc. Such activities require a substantial amount of labor and capital investment. Hence, this variable is a reasonable measure of the capital and labor investment effort undertaken by homesteaders. If a military presence does indeed support property right protection and afford a ready market for agricultural output, one would expect a greater degree of such investment in those areas were a fort is located. ${ }^{5}$

As stated earlier, the empirical analysis conducted here focuses on the region defined by the states of Kansas, Nebraska and Eastern Colorado. All three were states by 1880 and therefore county level census data is available. There appears to be substantial interest in the economic development of the American mid-West and Plains region evidenced by recent scholarship (Cunfer, 2005; Stewart, 2006). There may be several reasons for this interest. Prior to the outbreak of the Civil War, this region was largely considered uninhabitable and of little economic value. An early American explorer of the west, Stephen H. Long, described this region as "wholly unfit for cultivation...by a people depending on agriculture for their subsistence" and labeled the region "the Great American

\footnotetext{
${ }^{5}$ It may also be reasonable to suggest farm land values as an alternative measure of the economic impact of a frontier fort in that one would expect such land to be of higher value as potential settlers and/or land speculators bid up land prices for these attractive tracts of land if a fort affords a readily accessible market for agricultural goods as well as property right protection.. However, given that it is equally reasonable to hypothesize that a military presence would stimulate investment in land improvements, and given that several recent studies, notably Craig, Palmquist and Weiss (1998) and Decker and Flynn (2007) have found evidence that land values are strongly linked to acres improved, we might encounter an endogeneity problem were we to focus on land values directly. As we will see, we do find evidence that proximity to military establishment do stimulate investment in land improvements. Hence, indirectly, our findings support the notion that such proximity will also stimulate land values.
} 
Desert." ${ }^{\prime 6}$ Beginning in the 1860 s, this perception changed dramatically due to the passage of the Homestead Act, improved farming technology and transportation infrastructure, and increased efforts by "boosters". This dramatic change in perception resulted in an influx of citizens from the densely populated cities of the east.

This region developed into an agricultural economy that became a major contributor to the economic growth and development of the United States in the late nineteenth and early twentieth centuries. The combination of rapid world population growth and urbanization created substantial increases in world demand for food products, notably wheat (White, 1993, p. 244). As a result wheat became the major commodity in this region. In 1882, Kansas, Nebraska, and the Dakota territories accounted for 12 percent of total wheat production in the United States. By 1900, they accounted for 27 percent. By the second decade of the $20^{\text {th }}$ century, the United States, for the first time in its history, became a creditor nation. While manufacturing and other sectors certainly played a role in this, agriculture's role in this favorable trade balance cannot be overlooked (Walton and Rockoff, 1998, p. 460-61). This region has remained a major center of agriculture to this day.

Finally, the focus on this region is advantageous from an econometric perspective. Answering whether, and to what extent, forts impacted agricultural

\footnotetext{
${ }^{6}$ This excerpt has been quoted much in American history. This quote was taken from Hine and Faragher $(2000,160)$.
} 
investment requires that fort location be exogenous; that is, the presence of a military establishment induces agricultural investments, not that fort sites were selected in areas where land improvements have already taken place. The idea that forts may have been largely built in places that could best serve pioneers immigrating to westward to California or the Oregon Territories supports the notion that settlement and agriculture in the mid-West and Plains region largely followed after such fort installation reduces the potential for endogeneity. This said, below we do test for this potential reverse causality econometrically below.

The time period selected is worth noting as well. After the end of the Civil War, union army personnel were by-in-large redeployed to western regions of the nation to support, among other things, westward migration and protect settlers and capital (largely railroad and telegraph infrastructure) from Indian raids. Most territories in the Plains region had not yet, or had only recently achieved, statehood making reliable data from the 1860 and 1870 censuses largely incomplete. From 1890 through 1900, it became clear the end of the Plains Indian War was coming and many frontier military forts were being abandoned or demolished as the US frontier army was largely re-deployed to the nation's coastal areas for more rapid deployment overseas. ${ }^{7}$ As a result, to detect any potential link between economic development and agricultural development and

\footnotetext{
${ }^{7}$ Also with the end of frontier hostilities, the army began to cut down on enlistments, not fill any vacant military positions in frontier regions, and consolidate military operations in a few remaining western forts. This last point is of potential interest as a future research directive since it is not readily clear what criteria was applied to select forts for closure and forts for consolidation.
} 
the frontier Army, the 1880 period would offer the most reasonable time frame to focus upon.

\section{Model Variables and Data Sources}

The incentives to invest in agricultural land improvements are determined by the prevailing cost and demand considerations in the market for agricultural goods. On the cost side, land better suited for agricultural development will generate more efficient production and therefore offer homesteaders an opportunity to produce more efficiently (cost-effectively) than land less well suited for agricultural development. As a measure of the productive capacity of land, we construct a variable, YLD, again using data from the Census, which measures the ratio of bushels of agricultural crops produced to total acres planted for each county. ${ }^{8}$ We would expect more investment in improved acres to be associated with greater productive yield of the land. Moreover, easier access to markets as well as sources of productive capital can generate efficiencies in production. To address this, we include two variables. The first is a measure of the ratio of manufacturing employment to total population in a given county, MAN_EMP/POP, both taken from Census. Much of the manufacturing activities of this period and region were operations that supported the capital needs of local farmers, such as blacksmithing. The second variable, RR, indicates the presence

\footnotetext{
${ }^{8}$ The agricultural products used in this calculation were barley, buckwheat, corn, oats, rye, and wheat. It should be noted that this variable could also be influenced by the acres improved variable, ACIMP, in that higher productivity is likely influenced by the degree of improvements to land. This potential endogeneity will likely bias our statistical result. Therefore, our econometric procedures will address this issue.
} 
of a railroad line and is equal to one if the county in question contained a railroad passing through it as of 1876 . This data was generated by the authors from detailed inspection of state maps in the year 1876 as published by Rand McNally (see Table 1 for details). In both cases, we would expect greater improvements to land due to more manufacturing activities and the presence of a rail line.

With respect to market demand incentives to invest in agriculture, we include two population variables, POP/FARMS, and POPST/FARMST. The first variable is the ratio of county population to total number of farms. We expect that the greater the local demand for farm output (i.e. the greater the population relative to producers), the more investment in agricultural production will take place. It is also possible that some farm operations looked beyond the local market (as defined by county delineation). To proxy for farms in a given county having a wider market orientation we include the ratio of that population in a given state net of the population in county $i$, to total farms in the state, net of farms in a given county i. Again, we would expect a positive effect on agricultural investment here as well.

As for the effect of proximity to a frontier army fort, we generated two dummy variables, FORT, and NEARFORT. The FORT variable indicates the presence of at least one operating military fort in a given county $\mathrm{i}$ in 1880 . This 
data was compiled from maps published in Hart $(1963,1964) .{ }^{9}$ In addition, we constructed a variable NEARFORT which indicates, for a given county $i$, at least one fort located in a county adjacent to that county. In both cases, if proximity to a military fort stimulates agricultural investment, we would expect to see a positive effect.

In addition, we also include two state dummy variables indicating Kansas or Nebraska to capture state-specific elements that might otherwise be omitted by other variables. Recalling that our dataset covers these states plus eastern Colorado, it may be that there are certain state characteristics unique to each that might support agricultural land development. For instance, the fact that in 1880 Kansas had more population centers and therefore achieved statehood before Colorado may have given state legislators more time to influence agricultural development relative to Colorado. Once the various data sources are linked together, we end up with a 163 observations.

\section{Empirical Model Specification}

\footnotetext{
${ }^{9}$ Indeed, compiling this data was actually a bit more complicated. The maps published by Hart give a rough location of military forts and smaller military camps and the years in which these forts were in operation. Once those forts that were in operation in 1880 were identified, we conducted internet searches on each fort to pinpoint specific county location. At the time we also attempted to find data on garrison size in this period hypothesizing that not only proximity to a fort but the relative size of the military personnel present would also impact investment decisions. However, no such data was available either from individual internet sites nor from for sources, such as various government documents that addressed military budgets of the time. That said, we did take care to only include military forts and to exclude military posts, which as a rule tended to be smaller, of then with only one or two solders deployed at a given time and were more temporary in nature and construction.
} 
When implementing our empirical model, we could have used standard OLS, modeling the natural log of ACIMP as a function of the variables discussed above. However, doing so does not take into account that ACIMP is essentially bounded between zero and one since it is not possible to improved more acres in a county than are present. ${ }^{10}$ Hence, the resulting estimators cannot be assured unbiased and consistent. We therefore adopt a modeling procedure which explicitly takes this characteristic into account. ${ }^{11}$ Specifically, we assume, as is commonly done, ACIMP is a conditional probability that follows a logistical distribution. Using the independent variables discussed above, we estimate the following equation:

$$
\begin{aligned}
& \ln \left(\frac{\text { ACIMP }_{i}}{1-\text { ACIMP }_{i}}\right)=\beta_{0}+\beta_{1} \ln \left(Y_{L} D_{i}\right)+\beta_{2} \ln \left(\text { POP }_{i} / \text { FARMS }_{i}\right) \\
& +\beta_{3} \ln \left(\text { POPST }_{i} / \text { FARMST }_{i}\right)+\beta_{4} \ln \left(\text { MAN }_{-} E M P_{i} / \text { POP }_{i}\right) \\
& +\beta_{5} R R 1876_{i}+\beta_{6} \text { FORT }_{i}+\beta_{7} \text { NEARFORT }_{i} \\
& +\beta_{8} D M Y N E+\beta_{9} D M Y K S+e_{i},
\end{aligned}
$$

\footnotetext{
${ }^{10}$ A reasonable alternative specification may have been to model acres improved as a function of total acres plus the additional variables described above. This, however generated some statistical problems as total acres is highly correlated with some other model variables, such as population and agricultural yields. This potential multicollinearity could significantly bias our resulting standard errors. Modeling ACIMP as we have mitigates multicollinearity concerns (see Table 2).

${ }^{11}$ The procedure employed here comes largely from Greene (1993, p. 653-654) who provides a detailed background on the application of regression analysis to proportional data.
} 
where we use the log-form of our continuous independent variables. This was done because this specification generated the most desirable statistics. ${ }^{12}$

Under the logistic distribution assumption, so long as ACIMP lies between 0 and 1 , as is the case in our dataset, equation (1) can be estimated via OLS. ${ }^{13}$ The main econometric problem remaining, however, is that the variance of the resulting estimated residuals from such a regression are, by construction, heteroscedastic. To correct for this, we follow procedures detailed in Greene (1993, p. 654) and first estimate our model via OLS to obtain consistent estimates of the model parameters. The fitted equation is then used to construct weights that correct the heteroscedasticity problem. ${ }^{14}$ Equation (1) is then re-estimated via weighted least squares, the results of which are presented in Table 3.

\footnotetext{
${ }^{12}$ This also had the added benefit of allowing the resulting coefficients on our continuouslydefined variables to be interpreted, with some minor modification, as elasticities. To be sure, there are other legitimate functional forms that could have been estimated. Indeed, we investigated anther common form, the semi-log functional form whereby our continuous independent variables were included. This model produced higher regression errors and other less-desirable model statistics. Hence, we opt to focus on the log-linear form here. Results from this alternative specification are available upon request from the authors.

${ }^{13}$ To see this, let $y=$ LOSS/TONS. Then if $y$, conditioned on model variables, $x$, follows the logistic distribution, $y=\frac{\exp \left(x^{\prime} \beta\right)}{1+\exp \left(x^{\prime} \beta\right)}$. After some algebra, we have $\ln \left(\frac{y}{1-y}\right)=x^{\prime} \beta$.

${ }^{14}$ For the Logistic model, the error term $\varepsilon_{i}$ is heteroscedastic with a variance equal to $\operatorname{Var}(\varepsilon)=\frac{1}{n \Lambda_{i}\left(1-\Lambda_{i}\right)}$ where $\Lambda$ is the ACIMP and $n_{t}$ is the number of "trials" in county i. Notice the source of the heteroscedasticity in that the variance is not constant but rather changes with ACIMP. Hence, the weights used to estimate (1) are $w_{i}=\sqrt{n_{i} \Lambda_{i}\left(1-\Lambda_{i}\right)}$. Since $\Lambda_{i}$ is not known, we adopt the following two step procedure where we first estimate (1) via OLS and then calculate the fitted values of ACIMP: $\bar{\Lambda}_{i}$, which are used to construct $w_{t}$ and then used to re-estimate (1). The number of "trials" $n_{t}$, which in our case is the total number acres in a county. Again, see Greene (1993, p. 653-654) for further discussion of the logistic model.
} 
Another important econometric issue to address is the potential endogeneity between ACIMP and YLD. Productive yields would likely be higher with land improvements. To address this, we follow standard convention and estimate equation (1) via two-stage least squares (TSLS), instrumenting the YLD variable. $^{15}$

Finally, multicollinearity is a potential issue in any econometric exercise. For example, it may be that forts were located in close proximity to rail lines, suggesting a potentially high correlation between those two variables which could bias these variables' estimated standard errors upwards. Table 2 reports correlation coefficients between the independent variables defined in equation (1). Based on these statistics, there is little worry about statistical correlation between variables, lessening the collinearity concern. ${ }^{16}$

\footnotetext{
${ }^{15}$ Pendyck and Rubinfeld (1998) or Greene (1993) offers a good review of the TSLS procedure. In addition to the independent variables listed above, we include additional regressors necessary to identify the YLD equation in the initial stage of the TSLS procedure. In this equation, we include several regional variable indicators such as counties located east of the $98^{\text {th }}$ meridian (for Kansas and Nebraska) and whether or not a county had a river passing through it. One would expect yields to be effected by lands east of the $98^{\text {th }}$ meridian since rain fall is substantially higher in these locations relative the more arid conditions west of this delineation (see Webb, 1931). Moreover, if a county had a river passing through it might indicate easier access to water resource necessary for irrigation and cultivation. This too should directly impact yields. Finally, we include a variable: ACRES/FARMS, which measures the average size farm in a given county. To the extent that there are scale economies, one might expect productive yields to be higher on larger farms. These initial stage results, not presented here, are available upon request from the authors. It should be noted that an alternative approach to at least lessening the concern over endogeneity would be to obtain lagged YLD data from the 1870 census. Unfortunately, no such data is available.

${ }^{16}$ That said, two observations are worth highlighting. First, the correlation between RR1876 and YLD is relatively high, perhaps suggesting that yields benefited from rail access making it easier to ship inputs into the area and product out. Since RR1876 is included in the initial stage modeling YLD in the TSLS procedure however, this correlation is less of an issue. Second, one may be concerned with potential endogeneity between the establishments of forts and population.
} 


\section{Results}

The TSLS results are presented in Table 3. The regression results appear to be explaining about 68 percent of the dependent variable and the F-statistic implied that we can comfortably reject the null hypothesis that our coefficients are jointly equal to zero.

The key variable in our model is FORT, which proves to have a positive a statistically significant determinant of ACIMP, suggesting that, after controlling for other influences, greater capital investment and labor effort occurred in those counties where a fort was present. In terms of magnitudes, the results indicate that the presence of a nearby fort alone induces an increase in the proportion of improved acres of about 1.24 percent on average, relative to those counties that did not contain a fort. ${ }^{17}$ In light of previously published evidence by Craig, Palmquist, and Weiss (1998) and Decker and Flynn (2007), indicating that land values are significantly increased when land improvements occur, we conclude that forts offer incentives to land improvement behavior, and therefore tend to increase land values as well.

Specifically, one reason that the frontier army built forts in areas of greater settlement. While this is a possibility, there is little correlation between county population and the FORT variable. Second, Freedom's (1987, p. 10) research states that in many cases fort construction generally preceded settlement in many frontier regions.

${ }^{17}$ This effect was calculated in the following way. Since FORT is binary, we have for the Logit model, $\Delta \mathrm{y}=\mathrm{ACIMP}_{\mathrm{FORT}=1}-\mathrm{ACIMP}_{\mathrm{FORT}=0}=\frac{1}{\mathrm{e}^{-0.339}+1}=0.584$. To find the percent by which ACIMP is impacted, we follow convention and evaluate this percentage at the mean value of our dependent variable. Specifically, we calculate: $\Delta y / 47.1 \%=1.24$. 
The results also suggest closer proximity to a fort is more likely to induce increased agricultural development, evidenced by the smaller coefficient on NEARFORT. Also, at conventional significant levels, we cannot conclude that a fort located adjacent to a particular county induces more agricultural activity, although it is worth noting that the p-value is .126 , "close" to the standard 10 percent significance level.

The other variables in the model generally come through as expected. Land more conducive to agriculture, as proxied by YLD, tends to induce greater land improvement activity. Indeed, a ten percent increase in YLD results in a 3.97 percent increase in ACIMP. ${ }^{18}$ Moreover, those counties that have rail access by 1880 also appear to experience greater agricultural land improvements.

While the coefficients are as expected on $\ln (\mathrm{POP} / \mathrm{FARMS})$ and $\ln ($ MAN_EMP/POP), neither is statistically significant at conventional levels. Interestingly, larger state population relative to farms does not appear to prompt more land improvements in counties, suggesting that by 1880 many farming operations were inclined to look beyond local markets.

18 To calculate an elasticity for continuously defined variables, for the general logistic model: $\ln \left(\frac{y}{1-y}\right)=\beta \ln x$, the resulting elasticity is $\beta(1-y)$. Again, following convention we evaluate this elasticity at the mean of $y$. For the elasticity of YLD on ACIMP, we calculate $0.750 *(1-0.470) \approx 0.397$. 
Is the location of a fort endogenous to land improvements? The issue of how fort sites were determined is still open. One might suggest that forts were located in areas where some farming/ranching activity had already taken place. Such regions would be a potential source for food and other provisions required by the stationed garrisons, although correlation statistics do not support this assertion. That said, given that the underlying assumption in our model necessarily assumes that forts impact land improvement and not vice versa, it is worth addressing whether or not there is reason to suggest fort site selection depended on land improvements. The issue of site selection is complex and we do not presume to model the process completely, though we do offer some evidence that dampens the concern over reverse causality. To address this issue empirically, we collected data on the proportion of acreage improved to acres from the Ninth Decennial Census of the United States of 1870, compiled by ICPSR. We then created a binary variable, again using data from Hart (1963, 1964) that equals 1 when a military fort was constructed after 1870,0 otherwise. We then estimated the following model assuming a binary Probit ${ }^{19}$ :

$$
\begin{aligned}
\operatorname{Pr}\left(\text { FORT } \_P O S T 1870=\right. & =\Phi\left(\alpha+\beta_{1} \ln (\text { ACIMP1870 })\right. \\
& \left.+\beta_{2} \ln (\text { ACIMP } / \text { ACIMP1870 })+\beta_{3} D M Y K S\right) .
\end{aligned}
$$

\footnotetext{
${ }^{19}$ Note that we did lose data from Colorado as it was not a state in 1870 and we thus did not have county level data. This results in a reduced sample size to about 106 observations.
} 
If fort site was sensitive to improved acreage, as well as any improved acreage over the decade of the 1870 s, we should expect positive and significant coefficients on $\beta_{1}$ and $\beta_{2}$. The results are presented in Table 4. Neither variable appears to be a determining factor of fort site location, calling into question concerns that forts were selected in response to agricultural investment already taken place. ${ }^{20}$

Did a fort sustain agricultural development? We began this essay by discussing the relative value of governmental involvement in economic development and, in particular, the Homestead Act of 1862. The suggestion was that, while the act, and the several other land disposal acts that followed were largely a failure because they fostered small scale farming on land not suited for such operations, perhaps federal efforts to support farm success through settlement protection, etc., may have played a role in fostering such development. As the results above highlight, the establishment of military forts did foster land development.

However, these results do not offer clues as to the impact that military forts may have played in sustaining such agricultural efforts. This issue is important since the failure of a military presence to translate into sustained

\footnotetext{
${ }^{20}$ Note that the dummy variable for Kansas was included to capture any potential influence state political and other social differences may have played in fort location. Also note that the results are substantively the same either the level of acres improved in 1870 or the growth in acres improved is dropped from equation (2). Clearly, these results offer little insight as the cause of fort site selection. While beyond the scope of this study, such an analysis my be a fruitful avenue for future research.
} 
growth, further calls into question 1) whether or not the establishment of forts simply delayed the inevitable failure of the land acts and 2) whether or not the establishment of forts caused too much agricultural investment to take place, suggesting a socially inefficient commitment of agricultural capital investment and labor effort.

In this section, we address the issue of whether or not a fort constructed prior to 1880 but subsequently closed prior to 1890 resulted in sustained agricultural growth in both land improvements and number of farms. This hypothesis tests whether capital deepening in land improvement prompted by the presence of a fort in 1880 was sufficient to sustain growth even after the military (and the associated federal spending that supported the garrisons) exited the area. If the answer is "yes", such development was in fact sustained, then one would be inclined to conclude that the frontier army did create circumstances that supported development, perhaps mitigating the criticism of the Homestead Act of 1862. If, however, the answer is "no" one might conclude the frontier army only delayed the inevitable, that homesteading in certain regions was simply untenable.

We constructed two growth models to address this issue. The first models the growth in ACIMP between 1880 and 1890. The second models the growth in FARMS between 1880 and 1890. Data for 1890 on land improvements, ACIMP1890, 1890 farms, FARMS1890, county and state (net of county i) level population for 1890, POP1890 and POPST1890, and manufacturing employment 
in 1890, MAN_EMP1890, were all taken from the Eleventh Decennial Census of the United States of 1890, compiled by ICPSR. We constructed FORT_PRE1890, again from Hart $(1963,1964)$, which indicates those forts which were in operation in 1880 but subsequently closed prior to 1890 . Indeed, most forts in our dataset were indeed closed by 1890 . We also created a variable, RR_ADDED, which is a dummy variable indicating if a county that did not have a rail line in 1876 did receive such a line by the $1890 \mathrm{~s}^{21}$

We estimated the following equation via TSLS:

$$
\begin{aligned}
& \ln \left(\mathrm{X}_{1890_{\mathrm{i}}} / \mathrm{X}_{\mathrm{i}}\right)=\alpha \beta_{1} \ln \left(\mathrm{YLD}_{\mathrm{i}}\right)+\beta_{2} \ln \left(\mathrm{POP} 1890_{\mathrm{i}} / \mathrm{POP}_{\mathrm{i}}\right) \\
& +\beta_{3} \ln \left(\text { POPST1890 }_{\mathrm{i}} / \text { POPST }_{\mathrm{i}}\right. \text { ) }
\end{aligned}
$$

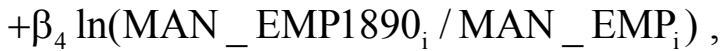

$$
\begin{aligned}
& +\beta_{5} \mathrm{RR}_{-} \mathrm{ADDED}_{\mathrm{i}}+\beta_{6} \mathrm{FORT}_{-} \mathrm{PRE} 1890_{\mathrm{i}} \\
& +\beta_{7} \mathrm{DMYKS}+\beta_{8} \mathrm{DMYNE}+\mathrm{e}_{\mathrm{i}}
\end{aligned}
$$

where $X_{i}$ equals either ACIMP or FARMS for a given county i. ${ }^{22}$ We would expect a positive coefficient on the two population growth variables as well as the manufacturing employment growth variable. We also would expect continued

\footnotetext{
${ }^{21}$ Annual data on rail construction by county is not available. To get a picture of the progression of rail construction through the period of interest we exploited data from the following web site http://www.livgenmi.com/1895/, which supplies data on the location of rail lines by state and county for the year 1895 . While there may be some concern that we have counted counties that may have had rails by 1895 but not as of 1890 , it is generally accepted that most of the major rail lines were build by the 1890s. Hence, while available data does not exist to verify with certainty, any bias in our data is likely small.

${ }^{22}$ Note that we still estimate our equation (3) using TSLS owning to the endogeneity of YLD being driven by locational and land attribute factors (such as the presence of a river in the county). We also account for potential heteroscedasticity using White's estimator. The results are not substantively different from OLS.
} 
growth due to the spreading of the railroad network. We would expect a negative coefficient on YLD (i.e. productive yields as of 1880 as a proxy for land quality) under the hypothesis that, as a measure of land quality, the most productive acres of land would be used for production first. Also, we control for potential differences across states. Finally, if the military was to sustain growth after fort abandonment, we would expect the coefficient of FORT_PRE1890 to be positive as well.

The results for the land improvement growth equation are presented in Table 5. We find that local population growth, local manufacturing growth, and the acquisition of a rail line increased growth in land development. We find, as expected, that higher productive yields in 1880 , ceteris paribus, tend to slow land development. Finally, we find that the initial presence of a military fort has no statistical impact on the growth of land development.

Turning attention to the growth in the number of farms, Table 6 , we find that farm growth was deterred by increases in population and manufacturing, contrary to the results presented in Table 5. This is likely due to a crowding out effect; the more population and manufacturing, the less land available for new farms. We also find, consistent with Table 5, that gaining rail access, ceteris paribus, did foster some farm growth. However, we find that the initial presence of a fort did not support continued farm development. Indeed, since our measure of farm growth is in fact net farm growth, some of the farms from 1880 failed by 
1890, thus slowing the overall growth in farms over the period. Apparently, even the presence of a military establishment could not salvage the nation's land disposal policies. ${ }^{23}$

\section{Conclusion}

In this paper we empirically investigated the relationship between agricultural development in Kansas, Nebraska, and Colorado and proximity to military forts in 1880 . We find that, ceteris paribus, agricultural investments are substantially higher in those counties where a military fort is present, suggesting that military forts had a stimulating impact on agricultural development in the Great Plains. However, the reverse is not true. There is no statistical support for the notion that forts necessarily located in counties where substantial investment already occurred. Moreover, we found that while the presence of a military fort has the effect of increasing agricultural development, there is no evidence that such a presence sustained agricultural development.

While federal expenditures on military support appear to have had an immediate impact on agricultural investments in land, capital and labor, it was not sustained. As a result, it is entirely possible that the presence of a fort prompted more investment that would otherwise have been warranted, suggesting that in the

\footnotetext{
${ }^{23}$ In and ideal world, it would be of value to look specifically at farm failure (and new farm additions). Indeed, it would be of interest to consider more directly the impact of military forts and farm failures. In light of the evidence presented here, it is likely that the presence of a nearby fort would not have delayed farm failures by much, if at all. Nonetheless, it would be useful to investigate this. However, such data is not available from the Census. We leave this for future research.
} 
end, not only could farm establishment growth not be sustained, more resources were devoted to such development that would be socially optimal.

There are several avenues of future research. For instance, a richer exploration of the determinants of fort locations would be an interesting exercise. Moreover, a breakdown of the determinants of farm failures and new farm formation specifically would offer some additional insights to the results presented in our Table 6. Finally, it would be of interest to compare these results to fort locations in and the development of mining operations in the nineteenth century and compare with the results we have found here for agricultural development. These we leave for future research. 


\section{Bibliography}

Anderson Terry L. and Peter J. Hill, "Evolution of Property Rights: A Study of the American West," Journal of Law \& Economics 18(1), 1975, pp. 163179.

-----------, “Race for Property Rights," Journal of Law \& Economics 33(1), 1990, 99. 177-197.

, The Not So Wild, Wild West: Property Rights on the Frontier. Stanford, CA: Stanford University Press. 2004.

Anderson, Terry L. and Donald R. Leal. Free Market Environmentalism. Boulder: Westview Press, Inc. 1991.

Becsi, Zsolt. Do State and Local Taxes Affect Relative State Growth?” Economic Review, March/April. 1996: pp. 18-36.

Besley, Timothy. "Property Rights and Investment Incentives: Theory and Evidence from Ghana," Journal of Political Economy 1995, 103(5): pp. 903-937.

Chandra, Amitabh, and Thompson, Eric. "Does Public Infrastructure Affect Economic Activity? Evidence from the Rural Interstate Highway System? Evidence From the Rural Interstate Highway System," Regional Science and Urban Economics. 30 (4) 2000: pp. 457-90.

Craft, Eric, D. "The Value of Weather Information Services for Nineteenth Century Great Lakes Shipping, American Economic Review. 1998. 88(5): pp. 1059-1076.

Craig, L., and R. Palmquist, and T. Weiss, "Transportation Improvements and Land Values in the Antebellum United States: A Hedonic Approach," Journal of Real Estate Finance and Economics 16(2), 1998, pp. 173-189.

Cunfer, Geoff. On the Great Plains: Agriculture and Environment. College Station: Texas A\&M University Press, 2005.

Decker, Christopher S., and Flynn, David T. "The Railroad's Impact on Land Values in the Upper Great Plains at the Closing of the Frontier," Historical Methods 40(1), 2007, pp. 28-38. 
Dobak, William A. Fort Riley and its Neighbors: Military Money and Economic Growth, 1853-1895. Norman, OK: University of Oklahoma Press. 1998.

Dunn Jr., Walter S. Opening New Markets: The British Army and the Old Northwest, Westport, CT. Praeger. 2002.

Frazer, Robert W. Forts of the West: Military Forts and Presidios and Posts Commonly Called Forts West of the Mississippi River to 1898, $7^{\text {th }}$ ed. Norman, OK: University of Oklahoma Press. 1988.

Freedom, Gary S. "The Role of the Military and the Spread of Settlement in the Northern Great Plains, 1866-1891," The Midwest Review 9, 1987: pp. 111.

Greene, William H., Econometric Analysis, Englewood Cliffs: Prentice-Hall, 1993.

Hansen, Zeynep Kocabiyik and Libecap, Gary D. "The Allocation of Property Rights to Land: US Land Policy and Farm Failure in the Northern Great Plains," Explorations in Economic History 2004, 42(2): 103-129.

Hart, Herbert, M. Old Forts of the Northwest. Seattle, WA: Superior Publishing Press. 1963.

---old Forts of the Southwest. Seattle, WA: Superior Publishing Press. 1964.

Hine, Robert V., and Faragher, John Mack. The American West: A New Interpretive History. New Haven, CT: Yale University Press, 2000

Hooker, Mark A. and Knetter, Michael M. "Measuring the Economic Effects of Military Base Closures," Economic Inquiry. 39(4), 2001: pp. 583-598.

Kmenta, Jan. 1986. Elements of Econometrics, $2^{\text {nd }}$ ed. New York: Macmillan.

Kanazawa, Mark. "Investment in Private Water Development: Property Rights and Contractual Opportunism During the California Gold Rush," Explorations in Economic History 2006, 43: pp. 357-381. 
Libecap, Gary D. and Hansen, Zeynep Kocabiyik. "'Rain Follows the Plow' and Dryfarming Doctrine: The Climate Information Problem and Homestead Failure in the Upper Great Plains, 1890-1925," The Journal of Economic History 2002, 62(1): pp. 86-120.

Lindert, Peter. "Long Run Trends in American Farmland Values." In Quantitative Studies in Agrarian History, ed. Morton Rothstein and Daniel Field. Ames: Iowa State University Press, 1993.

Malone, Laurence J. Opening the West: Federal Internal Improvements Before 1860. Westport, CT: Greenwood Press. 1998.

North, Douglass C. "Institutions, Transactions Costs and Economic Growth," Economic Inquiry 1987, 25(3): pp. 419-428.

--------------. Institutions, Institutional Change and Economic Performance, Cambridge, MA. Cambridge University Press.

Olson, James C. and Naugle, Ronald C. History of Nebraska, $3^{\text {rd }}$ ed. Lincoln, NE: University of Nebraska Press. 1997.

Pindyck, Robert S., and Rubinfeld, Daniel L. Econometric Models and Economic Forecast, $4^{\text {th }}$ ed. Boston, MA: Irwin McGraw-Hill. 1998.

Rand McNally's Pioneer Atlas of the American West. Chicago: Rand McNally \& Company, 1969.

Stewart, James I. "Migration to the Agricultural Frontier and Wealth Accumulation, 1860-1870," Explorations in Economic History. 2005, forthcoming.

Tate, Michael L. The Frontier Army in the Settlement of the West. Norman, OK: University of Oklahoma Press. 1999.

Tate, Michael L. The American Army in Transition, 1865-1898. Westport, CT: Greenwood Press. 2007.

Torstensson, Johan. "Property Rights and Economic Growth: An Empirical Study," Kyklos 1994, 47(2): pp. 231-247. 
U.S. Bureau of the Census. 1883-1888. Statistics of Population 1883, Volume I: Table 23.

U.S. Bureau of the Census. 1883. Report on the Production of Agriculture 1883, Volume III: Table 7.

Walton, Gary M., and Rockoff, Hugh. History of The American Economy, $8^{\text {th }}$ ed. New York: Dryden Press, 1998.

Webb, Walter P. The Great Plains. Lincoln: University of Nebraska Press, 1931.

White, Richard. It's Your Misfortune and None of My Own: A New History of the American West. Norman: University of Oklahoma Press, 1991. 
Table 1. Summary Statistics

\begin{tabular}{|c|c|c|c|}
\hline Variable & Definition & Mean & Standard Deviation \\
\hline ACIMP & Ratio of improved acres to total acres (1) & 0.471 & 0.225 \\
\hline YLD* & $\begin{array}{l}\text { Ratio of the number of bushels produced of } \\
\text { agricultural products to total acres planted (1) }\end{array}$ & 5.734 & 4.829 \\
\hline POP/FARMS & Ratio of county population to number of farms $(1,2)$ & 10.357 & 17.329 \\
\hline POPST/FARMST & $\begin{array}{l}\text { Ratio of state (minus county i) population to state } \\
\text { (minus county i) farms }(1,2)\end{array}$ & 10.070 & 9.975 \\
\hline MAN_EMP/POP & $\begin{array}{l}\text { Ratio of county manufacturing employment to } \\
\text { population ( } 2)\end{array}$ & 0.036 & 0.118 \\
\hline RR1876 & $\begin{array}{l}\text { dummy variable }=1 \text { if county had a railroad present as } \\
\text { of } 1876,0 \text { otherwise }(6)\end{array}$ & 0.539 & 0.500 \\
\hline FORT & $\begin{array}{l}\text { dummy variable }=1 \text { if county had a fort operating in } \\
1880,0 \text { otherwise }(5)\end{array}$ & 0.073 & 0.260 \\
\hline NEARFORT & $\begin{array}{l}\text { dummy variable }=1 \text { if a oucnty boardering a county } i \\
\text { had an operating fort in } 1880,0 \text { otherwise }(5)\end{array}$ & 0.255 & 0.437 \\
\hline ACRES/FARMS ** & Ratio of county total acres in farms to farms (1) & 179.921 & 82.749 \\
\hline DMY98 ** & $\begin{array}{l}\text { dummy variable }=1 \text { if county was east of the } 98 \\
\text { meridian, } 0 \text { otherwise (6) }\end{array}$ & 0.606 & 0.490 \\
\hline RIVER ** & $\begin{array}{l}\text { dummy variable }=1 \text { if county had a river, } 0 \text { otherwise } \\
\text { (6) }\end{array}$ & 0.788 & 0.410 \\
\hline ACIMP1890 (2) & Ratio of improved acres to total acres in 1890 (3) & 0.694 & 0.192 \\
\hline POP1890/FARMS1890 (2) & Ratio of county population to farms in 1890 (4) & 16.949 & 51.605 \\
\hline POPST1890/FARMST1890 (2) & $\begin{array}{l}\text { Ratio of state (minus county i) population to state } \\
\text { (minus county i) farms in } 1890 \text { (4) }\end{array}$ & 11.159 & 5.660 \\
\hline MAN_EMP1890/POP1890 (2) & $\begin{array}{l}\text { Ratio of county manufacturing employment to } \\
\text { population in } 1890 \text { (4) }\end{array}$ & 0.014 & 0.019 \\
\hline RR_ADDED $(4,6)$ & $\begin{array}{l}\text { dummy variable }=1 \text { if county had a railroad added by } \\
1895,0 \text { otherwise }(6,7)\end{array}$ & 0.477 & 0.501 \\
\hline FORT_PRE1890(5) & $\begin{array}{l}\text { dummy variable }=1 \text { if county had a fort as of } 1880 \\
\text { that closed before } 1890(5)\end{array}$ & 0.063 & 0.243 \\
\hline ACIMP1870 (2) & Ratio of improved acres to total acres in 1870 ( & 0.297 & 0.175 \\
\hline FORT_POST1870(5) & $\begin{array}{l}\text { dummy variable }=1 \text { if county had a fort built after } \\
1870 \text { (5) }\end{array}$ & 0.028 & 0.167 \\
\hline
\end{tabular}

*Note: the agricultural products were barley,

buckwheat, corn, oats, rye, and wheat.

**Note: these variables were used in the initial stage

of the TSLS procedure to sepecify YLD.

(1) Tenth Decennial Census of the United States 1880:

Volume III: Report on the Production of Agriculture,

Table 7.

(2) Tenth Decennial Census of the United States 1880:

Volume I: Statistics of Population, Table 3.

(3) Eleventh Decennial Census of the United States, 1890: Volume X: Report on Statistics of Agriculture, Table 14.

(4) Eleventh Decennial Census of the United States,

1890: POPULATION

(5) Hart $(1963,1964)$

(6) Rand McNally's Pioneer Atlas of the American

West, 1969 Edition, Rand McNally \& Company.

(7) Data can be found at

http://www.livgenmi.com/1895/ 
Table 2. Correlation Matrix

\begin{tabular}{|c|c|c|c|c|c|c|c|c|c|}
\hline & YLD & POP/FARMS & POPST/FARMST & RR1876 & FORT & NEARFORT & $\begin{array}{c}\text { MAN_EMP/ } \\
\text { POP }\end{array}$ & DMYNE & DMYKS \\
\hline YLD & 1.00 & -0.11 & -0.19 & 0.41 & -0.06 & -0.02 & -0.25 & 0.19 & -0.08 \\
\hline POP/FARMS & & 1.00 & 0.34 & 0.17 & 0.12 & -0.09 & 0.14 & -0.03 & -0.17 \\
\hline POPST/FARMST & & & 1.00 & 0.18 & 0.09 & 0.09 & -0.05 & -0.23 & -0.31 \\
\hline RR1876 & & & & 1.00 & 0.17 & 0.09 & -0.20 & -0.09 & -0.01 \\
\hline FORT & & & & & 1.00 & -0.16 & -0.05 & -0.08 & 0.03 \\
\hline NEARFORT & & & & & & 1.00 & 0.07 & -0.12 & 0.07 \\
\hline MAN_EMP/POP & & & & & & & 1.00 & -0.11 & 0.13 \\
\hline DMYNE & & & & & & & & 1.00 & -0.85 \\
\hline DMYKS & & & & & & & & & 1.00 \\
\hline
\end{tabular}


Table 3. Logit TSLS Results, 1880

Dependent variable: $\ln ($ ACIMP/(1-ACIMP))

$\mathbf{N}=163$

variable

Constant

coeff.

$-41.342$

$\ln ($ YLD)

0.750

0.261

10.576

Ln(POPST/FARMST)

0.307

0.339

0.137

0.065

18.951

18.957

p-value

0.077

0.000

0.346

RR1876

0.078

0.000

FORT

NEARFORT

Ln(MAN_EMP/POP)

DMYNE

DMYKS

0.683

Adj. R-squared

38.250

0.052

0.126

0.151

0.092

0.090

sig.

$*$

$* * *$

F-stat.

$* * *$

* - Significant at the 10 percent level.

** - Significant at the 5 percent level.

*** - Significant at the 1 percent level.

Table 4. Binary Probit results for Kansas and Nebraska counties Dependent variable: FORT_POST1870

$\mathbf{N}=\mathbf{1 0 6}$

variable

Constant

coeff.

p-value

Ln(ACIMP1870)

$-0.149$

0.894

LOG(ACIMP/ACIMP1870)

3.261

0.137

DMYKS

2.437

0.255

0.255

0.676

McFadden R-squared

0.198 
Table 5. TSLS Results for change in land improvements between 1880 and 1890 Dependent variable: $\ln ($ ACIMP1890/ACIMP)

$\mathrm{N}=162$

variable

$\mathrm{C}$

$\operatorname{Ln}(\mathrm{YLD})$

Ln((POP1890/FARMS1890)/(POP/FARMS))

Ln((POPST1890/FARMST1890)/(POPST/FARMST))

RR_ADDED

FORT_PRE1890

Ln((MAN_EMP1890/POP1890)/(MAN_EMP/POP))

DMYNE

DMYKS

coeff.

$-5.938$

$-0.301$

0.820

$-10.751$

0.199

$-0.148$

0.079

9.484

8.471

0.490

Adj. R-squared

F-stat. p-value

0.208

0.000

0.000

0.180

0.007

0.357

0.057

0.167

0.166

Estimated using White's Heteroskedasticity-Consistent Standard Errors \& Covariance

* - Significant at the 10 percent level.

** - Significant at the 5 percent level.

*** - Significant at the 1 percent level. 
Table 6. TSLS Results for change in the number of farms between 1880 and 1890 Dependent variable: $\ln ($ FARMS1890/FARMS)

$\mathrm{N}=162$

variable

coeff.

$\mathrm{C}$

$\operatorname{Ln}(\mathrm{YLD})$

Ln((POP1890/FARMS1890)/(POP/FARMS))

$-6.322$

$-0.050$

$-1.079$

Ln((POPST1890/FARMST1890)/(POPST/FARMST))

$-12.098$

RR_ADDED

0.154

FORT_PRE1890

$-0.156$

Ln((MAN_EMP1890/POP1890)/(MAN_EMP/POP))

DMYNE

$-0.251$

DMYKS

10.406

8.963

$\mathrm{p}$-value

sig.

0.034

0.316

0.000

$\star \star \star$

0.021

0.095

0.188

0.000

0.017

Adj. R-squared

0.671

F-stat.

31.326

$* * *$

Estimated using White's Heteroskedasticity-Consistent Standard Errors \& Covariance

* - Significant at the 10 percent level.

** - Significant at the 5 percent level.

*** - Significant at the 1 percent level. 